\title{
Oblikovalski dejavniki v estetski presoji novozgrajenih okolij in njihova vključenost v zakonodajo: primer Istanbula
}

Novozgrajena okolja v mestih, katerih značilnosti so se spremenile zaradi neoliberalnih procesov in prednostnih odločitev, so pogosto predmet kritik zaradi pomanjkanja estetske kakovosti. Zaradi teh kritik postaja estetska presoja tovrstnih okolij čedalje pomembnejša, pri čemer se pojavljata ključni vprašanji, kako lahko take presoje opravimo in kako lahko njihova dognanja vključimo v zakonodajo. Avtorici članka obe vprašanji obravnavata na primeru Istanbula, pri čemer določata in razvrščata formalne estetske dejavnike na podlagi faktorske analize in analize variance izsledkov ankete, ki sta jo leta $2017 \mathrm{v}$ Istanbulu opravili s tremi vzorčnimi skupinami (raziskovalci, oblikovalci in uradniki). Izsledki analiz kažejo, da se pri presojanju formalne estetike pogledi raziskovalcev razlikujejo od pogledov uradnikov in oblikovalcev. Poleg tega razkrivajo, da so značaj in identiteta, zelena gradn$\mathrm{ja}$ in neujemanje identitete in grajenih oblik pomembni dejavniki, ki vplivajo na urbano formalno estetiko novozgrajenih okolij. Avtorici članek skleneta z razpravo o tem, kako bi lahko te dejavnike na primeru Istanbula vključili v zakonodajo.

Ključne besede: estetska presoja, novozgrajeno okolje, oblikovalski dejavniki, formalni estetski parametri, Istanbul, Turčija 


\section{Uvod}

Študije, povezane z urbanim neoliberalizmom, kažejo, da so se zaradi neoliberalnih politik preoblikovali prostori v mestih po vsem svetu. Pod vplivom tovrstnih politik je konkurenčnost nujna za uspešen gospodarski razvoj mesta (Karaman, 2013). Mestni prostor je postal eden najbolj dobičkonosnih virov naložb, mesta pa uvajajo agresivne strategije trženja krajev, s katerimi želijo pritegniti čim več kapitala (Swyngedouw idr., 2002; Kuyucu in Unsal, 2010). Obsežni (mega)projekti, masovna stanovanjska gradnja ter gradnja nakupovalnih in poslovnih središč in hotelov s petimi zvezdicami so začeli preoblikovati mestna okolja (Kuyucu in Unsal, 2010; Özalp in Erkut, 2016). Novozgrajena okolja v mestih, katerih značilnosti so se spremenile zaradi neoliberalnih procesov in prednostnih odločitev, so pogosto predmet kritik zaradi pomanjkanja estetske vrednosti. Zaradi teh kritik postajajo razprave o urbani estetiki čedalje pomembnejše, ob tem pa se odpirata ključni vprašanji, kako lahko izvedemo estetske presoje novozgrajenih okolij in kako jih lahko vključimo v zakonodajo. Avtorici članka ti vprašanji obravnavata na primeru Istanbula. Iz raznih študij je razvidno, da je estetska presoja grajenega okolja odvisna tako od subjektivnih kot oblikovnih parametrov (Strenberg, 1991; Nasar, 1994). V raziskavi, obravnavani v tem članku, sta avtorici upoštevali samo formalne estetske parametre, pri čemer sta uporabili konkretnejša oblikovalska merila, ki jih je lažje vključiti v zakonodajo.

Istanbul je najpomembnejše gospodarsko, kulturno in turistično središče Turčije ter ima izjemno pomembno strateško lego na stičǐšcu Evrope in Azije. To mesto je po vsem svetu znano po svoji naravni lepoti in spomenikih, ki so se ohranili iz obdobja, ko je bilo mesto prestolnica rimskega, bizantinskega in turškega imperija (Kuban in Yalçın, 2010). Od začetka 21. stoletja pa se mesto pod vplivom neoliberalnega režima temeljito spreminja (Lovering in Turkmen, 2011; Karaman, 2013), zlasti zaradi razcveta gradnje, ki pa je odvisen od dogajanja na nepremičninskem trgu (Balaban, 2012). Istanbul tako hitro izgublja svoj edinstven značaj (Barfu Candan in Ozbay, 2014). Zaradi neoliberalne politike, vzpostavljene na začetku 21. stoletja, se je mesto fizično povečalo, hkrati pa so se pojavile številne nove prostorske, družbene, okoljske in ekološke težave, povezane z nezakonitimi naselji (tur. gecekondu), masovno gradnjo visokih stanovanjskih stavb, megaprojekti in njihovo vključenostjo $\mathrm{v}$ mestno tkivo, javnim prevozom in prometom ter infrastrukturo in prenatrpanostjo posameznih območij. Prizadeta je bila tudi urbana estetika Istanbula, saj je razmah gradnje močno prizadel formalno estetiko mesta, zlasti njegovo silhueto (slika 1). Zato je treba določiti dejavnike, ki vplivajo na urbano estetiko novozgrajenih okolij v Istanbulu, na podlagi česar bi se lahko sprejela politika, ki bi pomagala izboljšati formalno
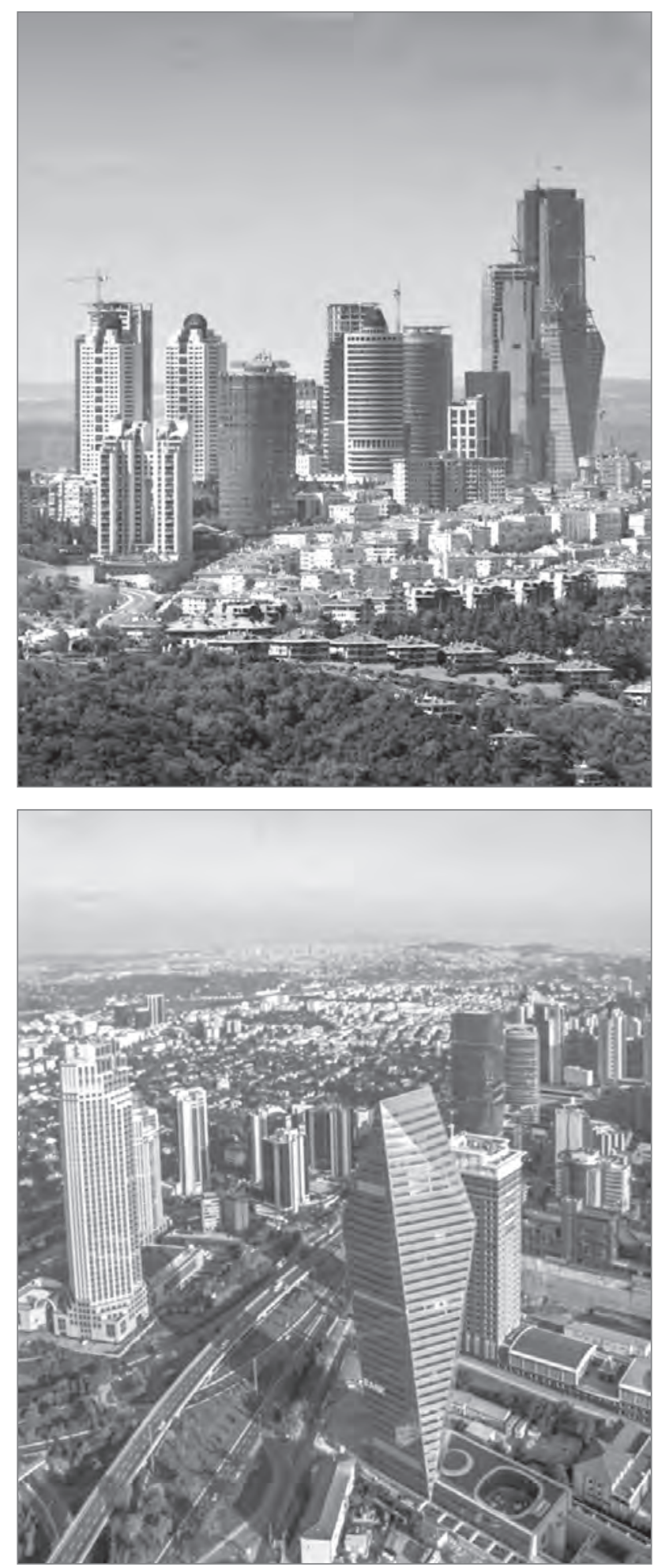

Slika 1: Razmah gradnje v Istanbulu (vir: GYODER, 2015)

estetiko mesta. Raziskava, obravnavana v tem članku, je lahko uporabna tudi za druga mesta, ki se spoprijemajo s podobno dinamiko gradnje.

V naslednjem poglavju sledi pregled literature, povezane z urbano estetiko, v tretjem poglavju pa se avtorici osredotočata na 
estetsko presojo grajenih okolij. V četrtem poglavju proučujeta oblikovalske dejavnike, ki se upoštevajo pri estetski presoji novozgrajenih okolij. Poglavje je razdeljeno na štiri podpoglavja: $\mathrm{v}$ prvem obravnavata zgradbo raziskave, $\mathrm{v}$ drugem podatke in postopek vzorčenja, $\mathrm{v}$ tretjem izsledke opravljenih analiz, $\mathrm{v}$ četrtem pa dejavnike estetske presoje novozgrajenih okolij, ki so že vključeni v zakonodajo. Članek končata s splošnim ovrednotenjem izsledkov in sklepi.

\section{Pregled literature o urbani estetiki}

Opredelitve, metodologije in kazalniki, uporabljeni v raziskavah urbane estetike, se med raziskavami razlikujejo, odvisno od raziskovalnega cilja. Kljub razlikam v pojmovanju se raziskovalci strinjajo, da je urbana estetika večdimenzionalen pojem. Kot razlaga Teymur (1981: 81), je izraz estetski pomensko vseprisoten. Uporablja se kot pridevnik, ki določa druge določevalne izraze, kot so kakovost, velikost, vrednost itd. Vsekakor je pozitiven pridevnik, ki nakazuje, da je nekaj dobro, lepo, prijetno, in ne slabo ali grdo. Estetski in estetika se nanašata tudi na cenjenje ali kritiko lepega, filozofijo ali znanost okusa ali zaznavanje lepote (Norton, 1967; Teymur, 1981). Tradicionalne opredelitve estetike se nanašajo na zaznavanje lepote $\mathrm{v}$ umetnosti ter lahko nakazujejo ekstremna in intenzivna občutja, kot je sublimnost (Nasar, 1997: 152).

Urbana estetika je subjektiven pojem, ki ga ni mogoče izmeriti (Sternberg, 1991: 70). Pehlivanoğlu (2011: 1) jo opisuje kot kompleksno prvino, ki mora vključevati več kot samo presojo fizičnih značilnosti mesta in pri kateri je treba upoštevati posameznikove izkušnje kot pomemben del kakovosti mestnega življenja. Nekateri avtorji menijo, da sta struktura in pomen osnova urbane estetike, drugi pa upoštevajo tudi pomen naravnega okolja, rabe zemljiščc, prometnih tokov, grajene oblike in vedenjskih vzorcev ljudi. Skratka, naravo urbane estetike določajo razmerja med stavbami in okoljem, dobro strukturirani prostorski prehodi in skladnost (Erdoğan, 2006: 72; Xiangzhan, 2008: 63; Mowla, 2011: 169). Na podlagi teh parametrov poskušajo načrtovalci razumeti večdimenzionalno naravo urbane estetike.

Obstaja več načinov presojanja estetike na mestnih območjih. Nasar (1994: 382) na primer razlikuje med formalno in simbolno estetiko mesta. Prva vključuje parametre, kot so oblika, proporci, ritem, merilo, kompleksnost, barva, osvetljenost, osenčenost in hierarhija in ki se nanašajo na fizične značilnosti stavb. Simbolno estetiko pa opredeljujejo parametri, kot je človekovo doživljanje zunanjosti stavb, ki se določajo na podlagi vsebinskih spremenljivk, ki pa ne temeljijo samo na fizičnih značilnostih. V nekaterih raziskavah je vprašanje urbane estetike razdeljeno na dva dela: na arhitekturne vred- note in urbano estetiko (King, 1997). Arhitekturna estetika je bolj povezana s fizičnimi značilnostmi stavb in prostora okrog njih, urbana estetika pa obsega precej širši nabor dejavnikov, pogojev in meril, kot so gospodarstvo, promet in onesnaženost. Ti pojavi, ki niso vedno vidni, vplivajo na dojemanje mesta in imajo pomembno vlogo pri tem, kako ljudje zaznavajo estetiko. Med te spadajo tudi kulturne in družbene vrednote, ki jih družba ali skupnost vnaša na mestno območje (King, 1997). Kot navaja Onaran (1995: 24), je človekovo estetsko doživljanje okolice neločljivo povezano s pomenom, ki ji ga pripisuje, in vezmi, ki jih z njo oblikuje. Bistvo estetike torej temelji na pojmih estetskega subjekta, objekta in vrednosti. Estetski objekt se nanaša na naravno okolje, prostorsko maso, površino in silhueto mesta. Velikost, oblika, lokacija ter medsebojna oddaljenost in usmerjenost objektov pa vplivajo na estetsko vrednost mestnega prostora (Pehlivanoğlu, 2011: 11). Estetski subjekt je dejavnik, ki je na področju estetike okolja opredeljen kot stvar okusa. Podobno Nasar (1990) navaja, da je vrednotenje podobe mestnega okolja odvisno od človekovi bioloških potreb, njegove osebnosti, družbeno-kulturnih izkušenj, stopnje prilagodljivosti, ciljev in pričakovanj. Ker je vsak človek drugačen in imajo ljudje različna občutja, potrebe in zahteve, ki vplivajo na obliko, pomen in funkcijo kraja, se tudi različno poistovetijo $s$ krajem in ga različno dojemajo. $\mathrm{V}$ eni izmed raziskav se je pokazalo, da proučevanje urbane estetike poteka na štirih ravneh (Alcock, 1993, navedeno v Pehlivanoğlu, 2011: 17), in sicer na ravni estetike razmerij, estetike načrta, umetniške estetike in družbene estetike. $V$ tem okviru se estetika razmerij nanaša na opazovalčevo razmerje ali odziv na vidni dražljaj visoke estetske kakovosti, estetika načrta se navezuje na objektivno vrednost geometrijskih razporeditev oblik (npr. geometrijskih hierarhij), umetniška estetika se nanaša na abstraktno izražanje idej z urbanističnim oblikovanjem, družbena estetika pa se osredotoča na subjektivno doživljanje prostora (Pehlivanoğlu, 2011: 17).

Urbana estetika je večdimenzionalna in kompleksna prvina, ki se lahko presoja simbolno ali z vidika oblike (forme), pri čemer je treba hkrati s posameznikovimi izkušnjami, vedenjskimi vzorci ter subjektivnimi vidiki in pomeni proučiti tudi fizične značilnosti, naravno okolje, rabo zemljiščc, prometne tokove in grajene oblike. Ker je namen raziskave, obravnavane $\mathrm{v}$ tem članku, proučiti urbano estetiko na način, ki bi ga lahko vključili v urbanistične zakone in predpise, so upoštevani samo formalni parametri estetike, saj se v zakonodajo lahko vključijo samo konkretnejši parametri. Zato so iz raziskave izključeni estetski dejavniki, kot so osebni okus pri presojanju estetike okolja, človekove biološke potrebe, osebnost, prilagodljivost, cilji, pričakovanja ter družbene, gospodarske in kulturne okoliščine in vrednote, ki jih družba vnaša na mestno območje; nobenega izmed teh dejavnikov namreč ne določajo izključno fizične značilnosti. 


\section{Estetska presoja grajenega okolja}

V literaturi lahko zasledimo le malo raziskav, povezanih z estetsko presojo grajenega okolja, in čeprav so cilji večine teh raziskav zelo podobni, avtorji uporabljajo zelo različno metodologijo, $s$ katero poskušajo opredeliti urbano estetiko.

Opravljenih je bilo več raziskav, povezanih z merjenjem estetske vrednosti grajenega okolja, ki temeljijo na zaznavanju (Strenberg, 1991; Pehlivanoğlu, 2011; Gomeshi in Mohd Jusan, 2013; Ahmad Nia idr., 2017; Gjerde, 2017). Ahmad Nia idr. (2017) so na primer proučevali estetske značilnosti mestnega prostora z morfološkega vidika, pri čemer so urbano estetiko določali na podlagi kronološkega pregleda širitve mesta skozi zgodovino. Avtorji so izbrali štiri soseske iz različnih obdobij rasti mesta, pri čemer so uporabili subjektivne in fizične parametre presoje urbane estetike. Iz njihove raziskave je razvidno, da se človekovo zaznavanje estetike mestnega okolja spreminja z njegovimi estetskimi vrednotami in znaćilnostmi. Gjerde (2017) je na podlagi anket, ki so jih izpolnili javnost ter oblikovalski in načrtovalski strokovnjaki, proučeval vizualne estetske zaznave mestne ulične krajine. Gomeshi idr. (2013) so raziskovali estetske preference arhitektov in nearhitektov pri oblikovanju pročelij stanovanjskih stavb. Pehlivanoğlu (2011) je proučeval zaznave, povezane z estetiko javnega mestnega prostora, pri čemer je upošteval razmerje med estetskim subjektom, objektom in vrednostjo.

Nekatere raziskave urbane estetike se osredotočajo na estetiko mestne krajine. Sahraoui idr. (2016) so proučevali mnenja o estetiki krajin, pri čemer so $\mathrm{v}$ anketi kot prostorske podatke uporabili niz merskih parametrov vidnosti krajin. Chen idr. (2009) so na podlagi celostne kvantitativne presoje proučevali estetsko vrednost zelenih mestnih prostorov, Cats-Baril in Gibson (1987) pa sta proučevala estetiko krajin ob pomoči strokovnjakov s področja oblikovanja.

Poleg zgoraj omenjenih raziskav so bile opravljene tudi druge raziskave, ki so se osredotočale na različne vidike urbane estetike. Çelik in Açıksöz (2017) sta na primer proučevala, kako se lahko trajnostna urbana estetika zagotavlja na podlagi oblikovalskih smernic. Crippen (2016) in Madanipour (1996) sta urbano estetiko proučevala s političnega vidika urbanističnega oblikovanja. Mokhtar (2007) je na podlagi primerjalne študije kritiziral neestetsko enoličnost sodobnih okolij, Nasar (1997) pa je na podlagi historiometrične raziskave in metode estetskega programiranja proučeval najnovejša dogajanja na področju estetike urbanističnega oblikovanja. Dimitrovska Andrews in Butina Watson (2001) sta kritično analizirali uspešne oblikovalske pobude za spodbujanje kakovostnega urbanističnega oblikovanja. $\mathrm{V}$ ta namen sta predlagali osnovna načela dobre urbane oblike na treh ravneh načrtovanja in oblikovanja: na ravni mestnega okolja in splošne kompatibilnosti (lokacija, raba zemljiščc, značilnosti okolja ali mestnega tkiva, merilo), ureditve in zunanjih vplivov (razporeditev javnega prostora, kakovost fizičnega prostora in krajinsko urejanje okolice) ter arhitekture in izvedbenega načrta (najobčutljivejši del urbanističnega oblikovanja: vrste stavb, slog, pročelja/višina in materiali).

Iz pregleda literature je torej razvidno, da estetska presoja grajenega okolja navadno temelji na zaznavanju in presoji številnih vidikov mestnega okolja. Čeprav so v raziskavah proučeni najrazličnejši vidiki (npr. estetika pročelij stanovanjskih stavb, ulic, javnega prostora, krajine ali mestnih zelenih prostorov), so raziskovalni cilji običajno enaki. Uporabljena metodologija obsega študije primerov, določanje merskih parametrov in opredelitev oblikovalskih smernic za presojo estetske kakovosti. V raziskave so bili vključeni javni uradniki, oblikovalski in načrtovalski strokovnjaki, arhitekti in splošna javnost. Kot že omenjeno, je objavljenih raziskav, povezanih z estetsko presojo novozgrajenih okolij, katerih izsledki bi bili lahko vključeni v zakonodajo, malo.

\section{Oblikovalski dejavniki estetske presoje novozgrajenih okolij \\ 4.1 Zgradba raziskave}

Raziskava je bila razdeljena v dve fazi. V prvi fazi sta avtorici določili oblikovalske dejavnike, ki se upoštevajo pri estetski presoji novozgrajenih okolij, in jih razvrstili na podlagi faktorske analize in analize variance (Anova). $V$ drugi fazi sta proučili, kako bi lahko te dejavnike vključili v zakonodajo $\mathrm{v}$ primeru Istanbula.

Urbana estetika se večinoma nanaša na zunanjo podobo objekta in kraja $\mathrm{v}$ izbranem mestnem okolju, razporeditev stavb ter skladnost in ustreznost kompozicije. $\mathrm{V}$ različnih virih so bila določena različna oblikovalska načela, ki se uporabljajo za povečanje estetske kakovosti grajenega okolja (Porteous, 1996; Nasar, 1997; DETR, 2000; Taylor, 2009; Celik in Acıksoz, 2017). Med njimi so tudi oblikovalski parametri, ki jih je določilo britansko ministrstvo za okolje, promet in regije (DETR, 2000). Ministrstvo je te parametre opredelilo z vidika značaja (kraj s svojo identiteto), kontinuitete in ograjenosti (kraj, kjer so javni in zasebni prostori jasno razpoznavni), kakovosti javnega prostora (kraj s privlačnimi in priljubljenimi območji na prostem), preprostosti gibanja (kraj, ki ga zlahka dosežemo in skozi katerega se zlahka gibamo), čitljivosti (kraj, ki ima jasno podobo in ga je lahko razumeti), prilagodljivosti (kraj, ki se zlahka spreminja) in raznolikosti (raznolik kraj s pestro izbiro; DETR, 2000: 15). Ti parametri se uporabljajo kot smernice 
Preglednica 1: Značilnosti skupin anketirancev

\begin{tabular}{|c|c|c|c|c|}
\hline Značilnosti anketirancev & $\begin{array}{l}\text { Raziskovalci } \\
(n=60)\end{array}$ & $\begin{array}{l}\text { Oblikovalci } \\
(n=37)\end{array}$ & $\begin{array}{l}\text { Uradniki } \\
(n=40)\end{array}$ & $\begin{array}{l}\text { Skupaj } \\
(n=137)\end{array}$ \\
\hline \multicolumn{5}{|l|}{ Spol } \\
\hline ženski & $42(70 \%)$ & $25(66 \%)$ & $24(60 \%)$ & $91(34 \%)$ \\
\hline moški & $18(30 \%)$ & $12(34 \%)$ & $16(40 \%)$ & $46(66 \%)$ \\
\hline \multicolumn{5}{|l|}{ Starost } \\
\hline $25-30$ & $13(22 \%)$ & $10(27 \%)$ & $6(15 \%)$ & $29(21 \%)$ \\
\hline $30-35$ & $8(13 \%)$ & $16(43 \%)$ & $13(33 \%)$ & $37(27 \%)$ \\
\hline $35-40$ & $1(1 \%)$ & $1(2 \%)$ & $14(35 \%)$ & $16(12 \%)$ \\
\hline $40-45$ & $13(22 \%)$ & $5(14 \%)$ & 7 (17\%) & $25(18 \%)$ \\
\hline$>45$ & $25(42 \%)$ & $5(14 \%)$ & $0(0 \%)$ & $30(22 \%)$ \\
\hline \multicolumn{5}{|l|}{ Zaposlitev } \\
\hline arhitekti & $38(64 \%)$ & 19 (51 \%) & $21(53 \%)$ & $78(57 \%)$ \\
\hline notranji oblikovalci & $6(10 \%)$ & $0(0 \%)$ & $0(0 \%)$ & $6(4 \%)$ \\
\hline krajinski arhitekti & $2(3 \%)$ & $2(5 \%)$ & $2(5 \%)$ & $6(4 \%)$ \\
\hline urbanistični načrtovalci & $12(20 \%)$ & $15(41 \%)$ & $15(37 \%)$ & $42(31 \%)$ \\
\hline urbanistični oblikovalci & $2(3 \%)$ & $1(3 \%)$ & $2(5 \%)$ & $5(4 \%)$ \\
\hline \multicolumn{5}{|l|}{ Dohodek (mesečni) } \\
\hline 2.500-3.000 TL & $8(14 \%)$ & $3(8 \%)$ & $1(3 \%)$ & $12(9 \%)$ \\
\hline 3.500-4.500 TL & $8(14 \%)$ & $10(27 \%)$ & $1(3 \%)$ & $19(14 \%)$ \\
\hline 4.500-5.500 TL & $17(28 \%)$ & $12(32 \%)$ & $25(62 \%)$ & $54(39 \%)$ \\
\hline $5.500-6.500 \mathrm{TL}$ & $10(16 \%)$ & $4(11 \%)$ & $10(25 \%)$ & $24(18 \%)$ \\
\hline$>6.500 \mathrm{TL}$ & 17 (28 \%) & 8 (22 \%) & 3 (7 \%) & 28 (20\%) \\
\hline
\end{tabular}

Opomba: TL pomeni turška lira.

za doseganje dobre prakse in učinkovito upravljanje. Avtorici sta pripravili vprašalnik, pri katerem sta upoštevali omenjene oblikovalske parametre in formalne parametre, ki sta jih našli $\mathrm{v}$ literaturi.

Vprašalnik vsebuje trideset vprašanj, s katerimi sta avtorici poskušali določiti oblikovalske dejavnike estetske presoje novozgrajenih okolij. Razdelili sta jih v tri skupine (podrobnosti so navedene $\mathrm{v}$ podpoglavju 4.2). Izsledke anket sta analizirali s statističnim programom SPSS 21, v katerega sta ročno vnesli zbrane podatke. Nato sta izvedli faktorsko analizo, $s$ katero sta določili omenjene oblikovalske dejavnike, pri čemer sta upoštevali relativen pomen njihovih komponent.

\subsection{Vzorčenje in podatkovna zbirka}

Za jasno določitev oblikovalskih dejavnikov, ki se upoštevajo pri estetski presoji novozgrajenih okolij, sta avtorici potrebovali mnenje strokovnjakov s področja urbanističnega oblikovanja. Uporabljena terminologija splošni javnosti ali nestrokovnjakom ne bi bila razumljiva, zato sta izbrali tri skupine strokovnjakov, ki so sodelovali v anketi: raziskovalce, uradnike in praktike s področja urbanističnega oblikovanja. Zadnjenavedeni so v članku poimenovani s skupnim izrazom oblikovalci. Vsi anketiranci so živeli v Istanbulu in poznajo novozgrajena okolja v mestu, zlasti tista, zgrajena po letu 2010. Ker v raziskavo ni bilo mogoče vključiti vseh strokovnjakov $s$ tega področja $v$ Istanbulu, sta avtorici izbrali reprezentativni vzorec.

Raziskovalce sta izbrali na oddelkih za arhitekturo in oblikovanje istanbulskih univerz. Kot je navedeno na spletni strani sveta za visoko šolstvo (Council of Higher Education, 2017), je v mestu 50 univerz z 32 oddelki za arhitekturo, notranje oblikovanje, urbanistično oblikovanje in načrtovanje ter krajinsko arhitekturo. Avtorici sta izbrali 60 anketirancev, ki so zastopali $5 \%$ vseh zaposlenih na teh oddelkih.

Drugo skupino anketirancev so sestavljali zaposleni v oblikovalskih birojih (oblikovalci). Avtorici sta izbor omejili na registrirane biroje v mestu. Po podatkih zbornic arhitektov, urbanistov in krajinskih arhitektov sta bila oktobra $2017 \mathrm{v}$ mestu 102 urbanistična biroja, poleg teh pa še 2.506 arhitekturnih birojev in 21 krajinskoarhitekturnih birojev. Avtorici sta izbrali 37 anketirancev izmed $10 \%$ vseh birojev.

Tretja skupina anketirancev je vključevala uradnike, zaposlene v občinskih upravah. Po podatkih spletne strani istanbulske metropolitanske občine je imelo mesto oktobra 201739 


\begin{tabular}{|c|c|c|c|c|c|}
\hline \multicolumn{6}{|c|}{ ODVISNE SPREMENLJIVKE } \\
\hline \multicolumn{2}{|c|}{$\begin{array}{l}\text { Stavbna in oblikovalska raven } \\
\text { (tridimenzionalne spremenljivke) }\end{array}$} & \multicolumn{2}{|c|}{$\begin{array}{l}\text { Stavbna (oblikovalska) in načrtovalska } \\
\text { raven } \\
\text { (dvo- in tridimenzionalne spremenljivke) }\end{array}$} & \multicolumn{2}{|c|}{$\begin{array}{l}\text { Načrtovalska raven } \\
\text { (dvodimenzionalne spremenljivke) }\end{array}$} \\
\hline 1 & $\begin{array}{l}\text { Velikost in kontinuiteta pozitivno } \\
\text { vplivata na urbano estetiko. }\end{array}$ & 13 & $\begin{array}{l}\text { Prevlada visokih stavb v silhueti mesta } \\
\text { negativno vpliva na urbano estetiko. }\end{array}$ & 19 & $\begin{array}{l}\text { Faktor izrabe gradbenih parcel neposre- } \\
\text { dno vpliva na urbano estetiko. }\end{array}$ \\
\hline 2 & $\begin{array}{l}\text { Red in hierarhija pozitivno vplivata } \\
\text { na urbano estetiko. }\end{array}$ & 14 & $\begin{array}{l}\text { Neenotni stavbni gabariti negativno } \\
\text { vplivajo na urbano estetiko. }\end{array}$ & 20 & $\begin{array}{l}\text { Pravilna ulična mreža pozitivno vpliva na } \\
\text { urbano estetiko. }\end{array}$ \\
\hline 3 & $\begin{array}{l}\text { Proporci, razmerja in ritem pozitivno } \\
\text { vplivajo na urbano estetiko. }\end{array}$ & 15 & $\begin{array}{l}\text { Razmerja med oblikami različnih sku- } \\
\text { pin stavb pozitivno vplivajo na urbano } \\
\text { estetiko. }\end{array}$ & 21 & $\begin{array}{l}\text { Neusklajenost gradbenih parcel } \mathrm{z} \text { identi- } \\
\text { teto okolice negativno vpliva na urbano } \\
\text { estetiko. }\end{array}$ \\
\hline 4 & $\begin{array}{l}\text { Merilo in volumen pozitivno vplivata } \\
\text { na urbano estetiko. }\end{array}$ & 16 & $\begin{array}{l}\text { Enolična masovna stanovanjska } \\
\text { gradnja negativno vpliva na urbano } \\
\text { estetiko. }\end{array}$ & 22 & $\begin{array}{l}\text { Neskladnost projektne gradnje s po- } \\
\text { drobnimi lokalnimi prostorskimi načrti } \\
\text { negativno vpliva na urbano estetiko. }\end{array}$ \\
\hline 5 & $\begin{array}{l}\text { Ponavljajoč se arhitekturni motiv } \\
\text { pozitivno vpliva na urbano estetiko. }\end{array}$ & 17 & $\begin{array}{l}\text { Raznolikost in vizualna pestrost pozi- } \\
\text { tivno vplivata na silhueto mesta. }\end{array}$ & 23 & $\begin{array}{l}\text { Zelene površine in zasaditve pozitivno } \\
\text { vplivajo na urbano estetiko. }\end{array}$ \\
\hline 6 & $\begin{array}{l}\text { Razmerje med pozidanim in praznim } \\
\text { prostorom v uličnih pročeljih pozitiv- } \\
\text { no vpliva na urbano estetiko. }\end{array}$ & 18 & $\begin{array}{l}\text { Ekološko krajinsko načrtovanje pozitiv- } \\
\text { no vpliva na urbano estetiko. }\end{array}$ & 24 & $\begin{array}{l}\text { Povezava z glavnimi pešpotmi pozitivno } \\
\text { vpliva na urbano estetiko. }\end{array}$ \\
\hline 7 & $\begin{array}{l}\text { Neskladnost pročelij z lokalnimi } \\
\text { načrti rabe zemljišč negativno vpliva } \\
\text { na urbano estetiko. }\end{array}$ & & & 25 & $\begin{array}{l}\text { Neskladnost višine stavb in širine cest } \\
\text { negativno vpliva na urbano estetiko. }\end{array}$ \\
\hline 8 & $\begin{array}{l}\text { Neskladnost oblike in strukture ne- } \\
\text { gativno vpliva na urbano estetiko. }\end{array}$ & & & 26 & $\begin{array}{l}\text { Izključujoči in odmaknjeni objekti nega- } \\
\text { tivno vplivajo na urbano estetiko. }\end{array}$ \\
\hline 9 & $\begin{array}{l}\text { Usklajene barve stavb pozitivno } \\
\text { vplivajo na urbano estetiko. }\end{array}$ & & & 27 & $\begin{array}{l}\text { Razmerje med pozidanim in praznim } \\
\text { prostorom pozitivno vpliva na urbano } \\
\text { estetiko. }\end{array}$ \\
\hline 10 & $\begin{array}{l}\text { Neskladnost tekstur, vzorcev in ma- } \\
\text { terialov negativno vpliva na urbano } \\
\text { estetiko. }\end{array}$ & & & 28 & $\begin{array}{l}\text { Slabo varovanje naravnega okolja in } \\
\text { ekosistemov negativno vpliva na urbano } \\
\text { estetiko. }\end{array}$ \\
\hline 11 & $\begin{array}{l}\text { Oblikovanost notranjih prostorov } \\
\text { vpliva na urbano estetiko. }\end{array}$ & & & 29 & $\begin{array}{l}\text { Pravilna usmerjenost stavb pozitivna } \\
\text { vpliva na urbano estetiko. }\end{array}$ \\
\hline 12 & $\begin{array}{l}\text { Uporaba ekoloških materialov pozi- } \\
\text { tivno vpliva na urbano estetiko. }\end{array}$ & & & 30 & $\begin{array}{l}\text { Oblikovanje urbane identitete na podla- } \\
\text { gi urbane estetike. }\end{array}$ \\
\hline
\end{tabular}

Slika 2: Odvisne spremenljivke (anketna vprašanja)

okrožnih občin in eno metropolitansko občino. Avtorici sta za raziskavo izbrali 40 anketirancev, po enega iz vsake občine. Značilnosti vseh treh skupin so navedene v preglednici 1 .

Anketni vprašalnik je bil razdeljen na dva dela. Prvi del je vključeval vprašanja, povezana z značilnostmi posamezne skupine anketirancev, drugi del pa je bil sestavljen iz vprašanj, povezanih z urbano formalno estetiko. Večina vprašanj prvega dela je bila oblikovanih tako, da so anketiranci lahko ovrednotili parametre formalne urbane estetike, ki se lahko določijo samo na podlagi fizičnih značilnosti. Z njimi sta avtorici želeli določiti konkretnejše oblikovalske parametre na stavbni, oblikovalski in načrtovalski ravni, ki bi jih lahko vključili v zakonodajo. Ta del je bil razdeljen na tri dele in je vseboval vprašanja, ki so se nanašala na stavbno (oblikovalsko) raven (tridimenzionalne spremenljivke) in načrtovalsko raven (dvodimenzionalne spremenljivke; glej sliko 2). Anketiranci so morali označiti stopnjo strinjanja z navedenimi trditvami na petstopenjski Likertovi lestvici ( 5 - popolnoma se strinjam, 4 - strinjam se, 3 - niti se strinjam niti se ne strinjam, 2 - se ne strinjam, 1 - sploh se ne strinjam). $S$ to metodo sta lahko avtorici oblikovalske dejavnike estetske presoje novozgrajenih okolij razvrstili po pomembnosti.

Prvih dvanajst vprašanj v drugem delu vprašalnika se je nanašalo na estetske parametre na stavbni (oblikovalski) ravni in na podatke o tridimenzionalnih značilnostih. Med njimi so bila vprašanja o velikosti, hierarhiji, redu, ritmu, proporcih, razmerju, merilu, volumnu, arhitekturnem motivu, razmerju med pozidanim in praznim prostorom, obliki pročelij, oblikovanosti notranjih prostorov, barvi, teksturi, vzorcih in materialih. Vprašanja št. 13-18 so se nanašala na formalne oblikovalske parametre na stavbni (oblikovalski) in načrtovalski ravni (vključevala so dvo- in tridimenzionalne spremenljivke) 
Preglednica 2: Izsledki analize variance

\begin{tabular}{|c|c|c|c|c|c|c|c|}
\hline \multirow[t]{2}{*}{ Spremenljivke } & \multicolumn{2}{|c|}{ Se strinjam } & \multicolumn{2}{|c|}{ Se ne strinjam } & \multicolumn{3}{|l|}{ Povprečja } \\
\hline & $n$ & $\%$ & $n$ & $\%$ & Raziskovalci & Uradniki & Oblikovalci \\
\hline 1 & 55 & 40,1 & 68 & 49,7 & 2,40 & 3,62 & 3,24 \\
\hline 2 & 79 & 57,7 & 42 & 30,6 & 3,85 & 2,72 & 3,08 \\
\hline 3 & 84 & 61,3 & 36 & 26,3 & 3,91 & 2,92 & 3,35 \\
\hline 4 & 69 & 50,4 & 44 & 32,1 & 3,78 & 2,32 & 3,02 \\
\hline 5 & 34 & 24,8 & 55 & 40,2 & 3,10 & 2,35 & 2,62 \\
\hline 6 & 62 & 30,3 & 50 & 36,5 & 3,20 & 2,90 & 2,94 \\
\hline 7 & 108 & 78,9 & 12 & 8,7 & 4,23 & 3,90 & 4,10 \\
\hline 8 & 111 & 81,0 & 12 & 8,8 & 4,26 & 4,20 & 3,91 \\
\hline 9 & 61 & 44,5 & 40 & 29,1 & 3,41 & 3,05 & 2,86 \\
\hline 10 & 103 & 75,8 & 10 & 7,3 & 3,98 & 3,85 & 4,38 \\
\hline 11 & 35 & 25,6 & 72 & 52,6 & 2,30 & 2,80 & 2,89 \\
\hline 12 & 66 & 48,2 & 40 & 29,2 & 2,90 & 3,72 & 3,43 \\
\hline 13 & 121 & 88,3 & 6 & 4,3 & 4,43 & 4,45 & 4,16 \\
\hline 14 & 123 & 89,8 & 9 & 6,6 & 4,36 & 4,65 & 4,18 \\
\hline 15 & 77 & 56,6 & 14 & 10,3 & 3,81 & 3,56 & 3,27 \\
\hline 16 & 110 & 80,3 & 12 & 8,8 & 4,33 & 4,02 & 3,94 \\
\hline 17 & 72 & 52,6 & 38 & 27,7 & 3,88 & 2,70 & 3,10 \\
\hline 18 & 97 & 70,8 & 17 & 12,4 & 3,98 & 3,82 & 4,08 \\
\hline 19 & 113 & 82,5 & 7 & 5,1 & 4,21 & 4,27 & 4,05 \\
\hline 20 & 45 & 33,1 & 44 & 32,3 & 3,31 & 2,89 & 2,51 \\
\hline 21 & 114 & 83,2 & 6 & 5,8 & 4,20 & 4,15 & 4,21 \\
\hline 22 & 105 & 76,7 & 9 & 6,5 & 4,25 & 4,17 & 3,86 \\
\hline 23 & 102 & 74,5 & 16 & 11,7 & 4,20 & 3,80 & 4,02 \\
\hline 24 & 94 & 68,6 & 24 & 17,5 & 3,46 & 3,95 & 3,91 \\
\hline 25 & 114 & 83,2 & 10 & 7,3 & 4,13 & 4,45 & 4,35 \\
\hline 26 & 98 & 71,6 & 13 & 9,5 & 4,05 & 4,05 & 3,97 \\
\hline 27 & 88 & 64,2 & 31 & 22,6 & 3,91 & 3,25 & 3,40 \\
\hline 28 & 119 & 86,8 & 7 & 5,1 & 4,20 & 4,37 & 4,56 \\
\hline 29 & 78 & 56,9 & 32 & 23,4 & 3,30 & 3,77 & 3,72 \\
\hline 30 & 104 & 75,9 & 17 & 12,4 & 4,30 & 3,90 & 3,86 \\
\hline
\end{tabular}

ter so se osredotočala na najpomembnejše značilnosti novozgrajenih okolij v zadnjih letih, zlasti v Istanbulu: vplive prevlade visokih stavb, neenotne gabarite stavb, različne oblike stavb, raznolikost in ekološko krajinsko oblikovanje. Vprašanja št. 18-29 so se nanašala na načrtovalsko raven in so vključevala dvodimenzionalne spremenljivke: faktor izrabe gradbenih parcel, načrtovanje pravilnih uličnih mrež, skladnost identitete parcel in okolice, projektno gradnjo, zeleno gradnjo, prometne tokove in usmerjenost stavb. Zadnje vprašanje se je nanašalo na razmerje med urbano identiteto in estetiko (slika 2).

\subsection{Izsledki analiz}

Da bi ugotovili zanesljivost uporabljene merske lestvice, sta avtorici izvedli analizo zanesljivosti v programu SPSS, ki je bil razvit za ugotavljanje zanesljivosti in izvirnosti testov, anket in merskih lestvic. Izsledki te analize so izraženi s Cronbachovim koeficientom alfa $(\alpha)$, vrednost katerega je za opisanih 30 vprašanj znašala 0,808 . Če je koeficient večji od 0,80 ali enak tej vrednosti in manjši od 1,00 ali enak tej vrednosti, je merska lestvica zelo zanesljiva (Kalayci, 2005: 405); analiza je torej pokazala visoko stopnjo zanesljivosti uporabljenega vprašalnika.

Izsledki analize variance (Anova) so pokazali, da so se anketiranci strinjali s $87 \%$ vprašanj ali trditev. V preglednici 2 sta navedeni frekvenci odgovorov Se strinjam in Se ne strinjam za vsako anketno vprašanje. $\mathrm{Na}$ desni strani so prikazana mnenja vsake od treh skupin anketirancev. Iz analize je razvidno še, da raziskovalci drugače vrednotijo urbano formalno estetiko kot uradniki in oblikovalci. 
Preglednica 3: Dejavniki in parametri

\begin{tabular}{|c|c|}
\hline Analizirani dejavnik & Vsebina dejavnika \\
\hline \multirow{9}{*}{ D1 Značaj in identiteta } & 1. Proporci, delež, ritem \\
\hline & 2. Merilo in volumen \\
\hline & 3. Red, hierarhija \\
\hline & 4. Velikost in kontinuiteta \\
\hline & 5. Raznolikost in vizualna pestrost \\
\hline & 6. Razmerje med pozidanim in praznim prostorom v uličnih pročeljih \\
\hline & 7. Barvna usklajenost \\
\hline & 8. Arhitekturni motiv \\
\hline & 9. Urbana identiteta \\
\hline \multirow{5}{*}{ D2 Zelena gradnja } & 1. Ekološko krajinsko načrtovanje \\
\hline & 2. Povezava z glavnimi pešpotmi \\
\hline & 3. Uporaba ekoloških materialov \\
\hline & 4. Pravilna usmerjenost stavb \\
\hline & 5. Zelene površine \\
\hline \multirow{5}{*}{ D3 Neujemanje identitete in grajenih oblik } & 1. Neujemanje oblik objektov \\
\hline & 2. Faktor izrabe gradbene parcele \\
\hline & 3. Identiteta parcele in okolice \\
\hline & 4. Razmerja med teksturami, vzorci in materiali \\
\hline & 5. Enolična masovna stanovanjska gradnja \\
\hline \multirow{3}{*}{ D4 Slabo varovanje kontinuitete in naravnega okolja } & 1. Razmerje med višino stavb in širino cest \\
\hline & 2. Slabo varovanje naravnega okolja in ekosistema \\
\hline & 3. Zaprti in odmaknjeni objekti \\
\hline \multirow{2}{*}{ D5 Visoke stavbe } & 1. Razmerje med višino stavb in širino cest \\
\hline & 2. Vplivi prevlade visokih stavb \\
\hline \multirow{2}{*}{$\begin{array}{l}\text { D6 Skladnost gradnje, ki temelji na sprejetih načrtih, in } \\
\text { projektne gradnje }\end{array}$} & 1. Neskladnost projektne gradnje s podrobnimi lokalnimi načrti \\
\hline & 2. Pravilna ulična mreža \\
\hline D7 Usklajenost skupin stavb & 1. Razmerja med oblikami različnih skupin stavb \\
\hline D8 Notranje oblikovanje & 1. Oblikovanost notranjih prostorov \\
\hline
\end{tabular}

Avtorici sta s programom SPSS opravili tudi faktorsko analizo, $s$ katero sta želeli ugotoviti, kateri oblikovalski dejavniki so najpomembnejši pri estetski presoji novozgrajenih okolij. Cilj faktorske analize je zmanjšati količino podatkov ter povzeti in razvrstiti izbrane parametre za lažjo interpretacijo in razumevanje povezav in vzorcev (Yong in Pearce, 2013: 79). $\mathrm{Za}$ testiranje ustreznosti raziskovalnih podatkov za faktorsko analizo sta avtorici uporabili Kaiser-Meyer-Olkinovo mero vzorčne ustreznosti. Rezultat testa $(0,772)$ je pokazal, da so podatki uporabni za faktorsko analizo.

Iz izsledkov faktorske analize, navedene v preglednici 3, je razvidno:

- prvi dejavnik (D1), imenovan značaj in identiteta, pojasnjuje $21,874 \%$ skupne variance. Označuje fizične lastnosti stavb in je sestavljen iz opazovalnih meritev značaja in identitete grajenih okolij;

- drugi dejavnik (D2), imenovan zelena gradnja, pojasnjuje 13,599 \% skupne variance. Označuje ekološke značil- nosti, ki se upoštevajo pri načrtovanju in oblikovanju, in je sestavljen iz meritev na načrtovalski ravni, povezanih z okolju prijazno gradnjo;

- tretji dejavnik (D3), imenovan neujemanje identitete in grajenih oblik, pojasnjuje 9,294 \% skupne variance. Nanaša se na značilnosti parcel, ki se upoštevajo pri načrtovanju in oblikovanju, ter vključuje meritve na načrtovalski in stavbni ravni;

- četrti dejavnik (D4), imenovan slabo varovanje kontinuitete in naravnega okolja, pojasnjuje 5,569 \% skupne variance. Nanaša se na značilnosti parcel, ki se upoštevajo pri oblikovanju, in vključuje meritve grajenega okolja na načrtovalski ravni;

- peti dejavnik (D5), imenovan visoke stavbe, pojasnjuje 5,235 \% skupne variance. Nanaša se na načrtovalske značilnosti grajenega okolja;

- šest dejavnik (D6), imenovan skladnost gradnje, ki temelji na načrtih, in projektne gradnje, pojasnjuje 4,176\% skupne variance. $V$ Turčiji se urbanistično načrtovanje 


\section{ZAKONODAJA, POVEZANA Z ESTETSKO PRESOJO}

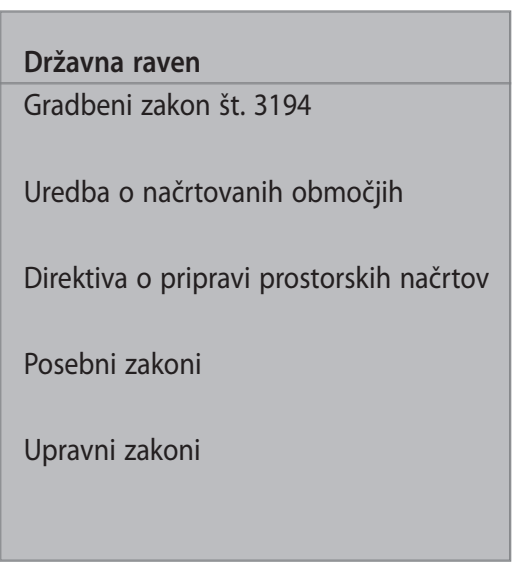

\begin{tabular}{l} 
Občinska raven \\
\hline Občinski gradbeni predpisi \\
Načrti rabe zemljišč najvišje ravni \\
Pojasnila k načrtom rabe zemljišč \\
najvišje ravni \\
Lokalni načrti rabe zemljišč \\
Pojasnila k lokalnim načrtom rabe \\
zemljišč
\end{tabular}

\begin{tabular}{l}
\hline Lokalna raven \\
\hline Podrobni lokalni načrti \\
nočrnilom k podrobnim lokalnim \\
Oblikovalske smernice \\
Odločbe komisij za arhitekturno \\
estetiko
\end{tabular}

Slika 3: Turška zakonodaja, povezana z estetsko presojo

\begin{tabular}{|c|c|c|}
\hline \multicolumn{3}{|c|}{$\begin{array}{l}\text { Členi, povezani z urbanističnim oblikovanjem in urbano estetiko v zakonih in predpisih, } \\
\text { ki se nanašajo na novozgrajena okolja v Istanbulu }\end{array}$} \\
\hline Zakoni in predpisi & $\begin{array}{l}\text { Členi, ki se nanašajo na urbanistično } \\
\text { oblikovanje in urbano estetiko }\end{array}$ & \\
\hline \multirow{4}{*}{ Gradbeni zakoni in predpisi } & Gradbeni zakon & $\begin{array}{l}\text { Oblike, parcele in njihova razlastitev, prilagoditev } \\
\text { zemljišč, oddaljenost stavb v ulici od roba ceste, } \\
\text { velikost pročelij, višina stavb }\end{array}$ \\
\hline & Uredba o načrtovanih območjih & $\begin{array}{l}\text { Standardi glede velikosti parcel, oddaljenosti dvo- } \\
\text { rišč od ceste, dimenzije stavb, pročelij, gradnje, } \\
\text { vpliva pročelij na značaj območja, števila in viš̌ine } \\
\text { nadstropij }\end{array}$ \\
\hline & Direktiva o pripravi prostorskih načrtov & $\begin{array}{l}\text { Standardi glede velikosti različnih območij, širine } \\
\text { pešpoti in cest, oblikovalske smernice }\end{array}$ \\
\hline & Gradbeni predpisi za Istanbul & $\begin{array}{l}\text { Standardi glede oblik, oddaljenosti dvorišč od } \\
\text { ceste, gradnje }\end{array}$ \\
\hline \multirow{4}{*}{ Posebni zakoni } & Okoljski zakon & Trajnostni razvoj, varovanje okolja \\
\hline & Zakon o masovni stanovanjski gradnji & $\begin{array}{l}\text { Zemljiške parcele in njihova razlastitev, trajnostni } \\
\text { razvoj }\end{array}$ \\
\hline & Zakon o spodbujanju turizma & Trajnostni razvoj, varovanje okolja \\
\hline & $\begin{array}{l}\text { Zakon o preobrazbi območij, ki jim grozijo } \\
\text { naravne nesreče }\end{array}$ & $\begin{array}{l}\text { Parcele, prilagoditev zemljišč, trajnostni razvoj, } \\
\text { varovanje okolja }\end{array}$ \\
\hline \multirow{2}{*}{ Upravni zakoni } & Zakon o metropolitanskih občinah & $\begin{array}{l}\text { Zagotavljanje skladnosti v okviru načrta, pročelja } \\
\text { stavb, standardi glede ulic in bulvarjev ter velikosti } \\
\text { in oblike oglasnih tabel }\end{array}$ \\
\hline & Zakon o občinah & $\begin{array}{l}\text { Standardi glede velikosti in oblike oglasnih tabel, } \\
\text { posegih v prostor, gradnje hiš in pravilne } \\
\text { urbanizacije }\end{array}$ \\
\hline \multirow[t]{2}{*}{ Drugi pravni instrumenti } & Načela komisije za arhitekturno estetiko & $\begin{array}{l}\text { Odločanje o tem, ali arhitekturni projekti izražajo } \\
\text { izvirne ideje (v skladu z zakonom o obnovi lahko } \\
\text { ustrezni organi na podlagi smernic, ki jih določi } \\
\text { ministrstvo, ustanovijo komisijo za arhitekturno } \\
\text { estetiko) }\end{array}$ \\
\hline & Oblikovalske smernice & Oblika, parcele, širina ulic, silhueta mesta \\
\hline
\end{tabular}

Slika 4: Zakonski členi, povezani z urbanističnim oblikovanjem in urbano estetiko v Istanbulu 


\begin{tabular}{|c|c|c|c|}
\hline \multicolumn{2}{|c|}{ Pravni instrumenti, ki veljajo za Istanbul } & \multicolumn{2}{|c|}{$\begin{array}{l}\text { Povezave med zakoni in predpisi ter osmimi } \\
\text { ugotovljenimi dejavniki }\end{array}$} \\
\hline & & Jih ni & Delna povezava \\
\hline \multirow{5}{*}{ Gradbeni zakoni in predpisi } & Gradbeni zakon & D2, D3, D4, D7, D8 & D1, D5, D6 \\
\hline & Uredba o načrtovanih območjih & D3, D7, D8 & D1, D2, D4, D5, D2, D6 \\
\hline & Direktiva o pripravi prostorskih načrtov & D1, D4, D7, D8 & D2, D3, D5, D6 \\
\hline & Gradbeni predpisi za Istanbul & D7, D8 & D1, D2, D3, D4, D5, D6 \\
\hline & Pojasnila k načrtom & D3, D4, D5, D6, D7, D8 & D1, D2 \\
\hline \multirow{4}{*}{ Posebni zakoni } & Okoljski zakon & D1, D2, D3, D5, D6, D7, D8 & D4 \\
\hline & Zakon o masovni stanovanjski gradnji & D5, D6, D7, D8 & D1, D2, D3, D4 \\
\hline & Zakon o spodbujanju turizma & D2, D3, D4, D5, D6, D7, D8 & D1 \\
\hline & $\begin{array}{l}\text { Zakon o preobrazbi območij, ki jim grozijo } \\
\text { naravne nesreče }\end{array}$ & D3, D4, D5, D6, D7, D8 & D1, D2 \\
\hline \multirow{2}{*}{ Upravni zakoni } & Zakon o metropolitanskih občinah & D1, D3, D5, D6, D7, D8 & D2, D4 \\
\hline & Zakon o občinah & D1, D3, D5, D6, D7, D8 & D2, D4 \\
\hline \multirow{2}{*}{ Drugi pravni instrumenti } & Načela komisije za arhitekturno estetiko & D2, D5, D6, D7, D8 & D1, D3, D4 \\
\hline & Oblikovalske smernice & D7, D8 & D1, D2, D3, D4, D5, D6 \\
\hline
\end{tabular}

Slika 5: Povezave med zakoni in predpisi o novozgrajenih okoljih ter osmimi ugotovljenimi dejavniki v Istanbulu

izvaja na podlagi regulativnega načrtovalskega sistema. Čeprav se pri načrtovanju pogosto upošteva pravilna ulična mreža, se zlasti po letu 2000 čedalje bolj krepi projektna gradnja, ki ne upošteva veljavnega načrtovalskega sistema (Ozkan in Turk, 2016). Dejavnik se nanaša na načrtovalske značilnosti grajenega okolja;

- sedmi dejavnik (D7), imenovan usklajenost različnih skupin stavb, pojasnjuje 3,942\% skupne variance in se nanaša na načrtovalske značilnosti grajenega okolja;

- osmi dejavnik (D8), imenovan notranje oblikovanje, pojasnjuje 3,857 \% skupne variance in se nanaša na značilnosti stavb v grajenem okolju.

\subsection{Oblikovalski dejavniki estetske presoje novozgrajenih okolij v veljavni zakonodaji}

Iz izsledkov faktorske analize je razvidno, da je dejavnik značaj in identiteta najpomembnejši dejavnik, ki vpliva na urbano formalno estetiko. Sledijo mu dejavniki, kot so zelena gradnja, neskladnost grajenih oblik in identitete, slabo varovanje kontinuitete in naravnega okolja, visoke stavbe, neskladje med gradnjo, ki temelji na sprejetih načrtih, in projektno gradnjo, usklajenost različnih skupin stavb in oblikovanost notranjih prostorov. V nadaljevanju avtorici proučujeta, ali so ti dejavniki vključeni v veljavno zakonodajo.

Zakonodajo, povezano z estetsko presojo, lahko v Turčiji in Istanbulu razdelimo na tri ravni: državno, mestno in lokalno (glej sliko 3).

Zakonski členi, povezani z urbanističnim oblikovanjem in urbano estetiko, ki se nanašajo na zemljiške parcele, ceste, objekte in silhueto mesta, so povzeti na sliki 4. Povezave med zakoni in osmimi ugotovljenimi dejavniki so prikazane na sliki 5, na kateri so navedeni zakoni in predpisi, ki vsebujejo določbe, povezane s temi osmimi dejavniki. Hkrati so na njej nakazani pravni pristopi $\mathrm{k}$ reševanju težav, povezanih $s$ temi dejavniki.

Na podlagi analize zakonodaje, povezane z novozgrajenimi okolji, ter primerjave slik 4 in 5 lahko ugotovimo, da večina pravnih instrumentov ponuja samo splošen opis dejavnikov. Na primer gradbeni zakon vsebuje samo nekaj splošnih določb glede merila, volumna, oblike pročelij, barvne usklajenosti in ekološkega krajinskega načrtovanja, ki se nanašajo na prvi dejavnik (značaj in identiteta). Nekateri drugi dejavniki se pojavljajo v direktivi o pripravi prostorskih načrtov (pod skupnim pojmom oblikovalske smernice) ter $\mathrm{v}$ posebnih in upravnih zakonih in drugih pravnih instrumentih. Kratke pojavitve opozarjajo na razdrobljenost določb, povezanih z urbano formalno estetiko, ki ne vsebujejo podrobnosti o tem, kako je treba razvijati urbano formalno estetiko novozgrajenih okolij. $\mathrm{Na}$ splošno bi lahko rekli, da ni podrobnih pravnih instrumentov, povezanih z urbano formalno estetiko.

\section{Sklep}

Pri preobrazbi mestnih prostorov pod vplivom neoliberalnih politik in prednostnih odločitev so spreminjajoče se mestne značilnosti predmet kritik zaradi pomanjkanja estetske kakovosti. To velja zlasti za obdobje po letu 2010 , ko se identiteta in tekstura teh območij v načrtih ne upoštevata. Pojem urbane estetike zato postaja čedalje pomembnejši. Čeprav je bilo opravljenih mnogo raziskav urbane estetike, jih le malo obravnava urbano formalno estetiko novozgrajenih okolij. V raziskavi, 
obravnavani v tem članku, sta avtorici na podlagi faktorske analize določili najpomembnejše dejavnike, ki vplivajo na urbano formalno estetiko. Hkrati sta razkrili, kateri dejavniki niso vključeni v zakonodajo in bi jih bilo treba dodati, da bi s tem ustrezno uredili urbano formalno estetiko v novozgrajenih okoljih. Iz primerjave teh dejavnikov na primeru Istanbula se razkriva razdrobljenost določb, povezanih z urbano estetiko, $\mathrm{v}$ zakonih in ugotoviti je mogoče, da so nekateri dejavniki v zakonodajo vključeni zelo pomanjkljivo.

Iz analize je poleg tega razvidno, katere parametre posameznih dejavnikov bi bilo treba vključiti v zakonodajo in koliko. Nekateri parametri so bolj splošni, drugi so podrobnejši, vse pa bi lahko v ustreznem obsegu vključili v državno, mestno in lokalno zakonodajo. D1 (značaj in identiteta), D2 (zelena gradnja), D4 (varovanje kontinuitete in naravnega okolja), D5 (visoke stavbe) in D6 (skladnost gradnje, ki temelji na načrtih, in projektne gradnje) se nanašajo na splošna vprašanja na državni ravni, ki bi jih bilo treba vključiti v gradbeni zakon in posebne zakone. Njihovi parametri, kot so proporci, merilo, hierarhija, velikost in raznolikost (D1), oblika objektov (D3) in razmerje med višino stavb in širino cest (D5), bi bilo treba vključiti v gradbeni zakon na splošni ravni, parametri, kot so razmerje med pozidanimi in praznimi površinami $\mathrm{v}$ uličnih nizih, usklajenost barv in arhitekturni motiv (D1), ekološko krajinsko načrtovanje, povezava z glavnimi pešpotmi, pravilna usmerjenost stavb, zelene površine in ekološki materiali (D2), razmerje med teksturo, vzorci in materiali (D3), razmerje med višino stavb in širino cest ter vpliv prevlade visokih stavb (D5), razmerja med različnimi skupinami stavb (D7) in oblikovanost notranjih prostorov (D8), pa bi morali biti predmet podrobnih lokalnih načrtov in njihovih pojasnil ter odločb komisij za arhitekturno estetiko na lokalni ravni. Parametri, kot so projektna gradnja, pravilna ulična mreža in skladnost projektne gradnje s podrobnimi lokalnimi načrti (D6), bi morali biti upoštevani v gradbenem zakonu. Podobno je enolična masovna stanovanjska gradnja (D3) aktualno vprašanje, ki bi ga morali reševati na državni ravni v okviru gradbenega zakona. Parameter varovanje naravnega okolja in ekosistemov (D4) bi lahko vključili v zakon o občinah na državni ravni. Urbana identiteta (D1), razmerje med parcelo in stavbo ter razmerje med identiteto parcele in okolice (D3) so vprašanja na mestni ravni, ki bi jih bilo treba dodati načrtom rabe zemljišč najvišje ravni, lokalnim načrtom rabe zemljišč, podrobnim lokalnim načrtom in njihovim pojasnilom. Najpomembnejše pa je, da so ti zakoni in predpisi med seboj usklajeni. Pomemben vidik zajemata tudi sposobnost ter raven načrtovalskega in oblikovalskega znanja strokovnjakov, ki sodelujejo pri načrtovalskih in oblikovalskih procesih. Tudi ti strokovnjaki morajo delovati usklajeno, zlasti pri podajanju navodil ter izvedbi in vodenju projektov. Kot je razvidno iz analize, se mnenja raziskovalcev pri presoji urbane formalne estetike razlikujejo od mnenj uradnikov in oblikovalcev.
Te cilje lahko dosežemo z upoštevanjem in uporabo navedenih dejavnikov v novozgrajenih okoljih na stavbni in načrtovalski ravni. Raziskava je razkrila veliko potrebo po preureditvi pravnih instrumentov, zlasti v primeru mest, kot je Istanbul najpomembnejše turško gospodarsko, kulturno in turistično središče. Izsledki, pridobljeni na primeru tega mesta, so lahko uporabni tudi za druge države, katerih mesta se spoprijemajo $s$ podobnimi dinamičnimi razvojnimi procesi.

\section{Azadeh Rezafar}

Univerza Istanbul Arel, Fakulteta za gradbeništvo in arhitekturo, Oddelek za arhitekturo, Istanbul, Turčija

E-naslov: azadehrezafar@arel.edu.tr

Sevkiye Sence Turk

Tehnična univerza v Istanbulu, Fakulteta za arhitekturo, Oddelek za urbanistično in regionalno prostorsko načrtovanje, Istanbul, Turčija E-naslov: turkss@itu.edu.tr

\section{Viri in literatura}

Ahmad Nia, H., Alpar Atun, R., in Rahbarianyazd, R. (2017): Perception based method for measuring the aesthetic quality of the urban environment. Open House International, 42(2), str. 11-19.

Balaban, O. (2012): The negative effects of construction boom on urban planning and environment in Turkey: Unraveling the role of the public sector. Habitat International, 36(1), str. 26-35.

DOI: 10.1016/j.habitatint.2011.05.003

Barfu Candan, A., in Özbay, C. (2014): Yeni İstanbul Çalışmaları: Sınırlar, Mücadeleler, Açılımlar. Istanbul, Metis Yayınları.

Cats-Baril, W., in Gibson, L. (1987): Evaluating landscape aesthetic: A multi-attribute utility approach. Landscape and Urban Planning, 14, str. 463-480. DOI: 10.1016/0169-2046(87)90060-0

Celik, D., in Acıksoz, S. (2017): Urban aesthetic and urban landscape design guides: A case study of Bartin-Turkey. Journal of Environmental Biology, 38(5), str. 893-901. DOI: 10.22438/jeb/38/5(SI)/GM-04

Chen, B., Adimo, O., in Bao, Z. (2009): Assessment of aesthetic quality and multiple functions of urban green space from the users' perspective: The case of Hangzhou Flower Garden, China. Landscape and Urban Planning, 93(1), str. 76-82. DOI: 10.1016/j.landurbplan.2009.06.001

Council of Higher Education (2017): Dostopno na: http://www.yok.gov. tr/web/guest/universitelerimiz (sneto 16. 10. 2017).

Crippen, M. (2016): Intuitive cities: Pre-reflective, aesthetic and political aspects of urban design. Journal of Aesthetics and Phenomenology, 3(2), str. 125-145. DOI: 10.1080/20539320.2016.1256067

DETR (2000): By design. Urban design in the planning system: Toward better practice. London, Commission for Architecture and the Built Environment.

Dimitrovska Andrews, K., in Butina Watson, G. (2001): City urban design in a free market economy - The case of Ljubljana, Slovenia. Urban Design International, 6(3-4), str. 143-155.

DOI: $10.1057 /$ palgrave.udi.9000054

Erdoğan, E. (2006): Çevre ve kent estetiği. ZKÜ Bartın Orman Fakültesi Dergisi, 8(9), str. 68-77.

Gjerde, M. (2018): Visual aesthetic perception and judgement of urban streetscapes. Dostopno na: http://www.irbnet.de/daten/iconda/ CIB18896.pdf (sneto 24. 10. 2018). 
Gomeshi, M., in Mohd Jusan, M. (2013): Investigating different aesthetic preference between architects and non-architects in residential façade designs. Indoor and Built Environment, 22(6), str. 952-964. DOI: $10.1177 / 1420326 \times 12458513$

GYODER (2015): A new vision for growth. Restructuring of Istanbul: Reconnection, regeneration, resettlement. str. 2-4. Istanbul, Cumhuriyet Caddesi Pegasus Evi.

Husukic, E., in Zejnilovic, E., (2017): The environmental aesthetics of Sarajevo: A city shaped by memory. Urbani izziv, 28(1), str. 96-106. DOI: 10.5379/urbani-izziv-en-2017-28-01-002

Karaman, O. (2013): Urban renewal in Istanbul: Reconfigured spaces, robotic lives. International Journal of Urban and Regional Research, 37(2), str. 715-733. DOI: 10.1111/j.1468-2427.2012.01163.x

King, J. (1997): Aesthetics in integrated conservation planning. Urban space and urban conservation as an aesthetic problem. V: Algreen-Ussing, G., Bek, L., Frandsen, S. B., in Schjerup-Hansen, J. (ur.): Aesthetics in integrated conservation planning: A consideration of its value, str. 19-26. Rim, L'Erma di Bretschneider.

Kuban, D., in Yalçın, E. (2010): Istanbul: An urban history: Byzantion, Constantinopolis, Istanbul. Istanbul, Türkiye İş Bankası Kültür Pub.

Kuyucu, T., in Ünsal, Ö. (2010): Urban transformation as state-led property transfer: An analysis of two cases of urban renewal in Istanbul. Urban Studies, 47(7), str. 1479-1499. DOI: 10.1177/0042098009353629

Lovering, J., in Turkmen, H. (2011): Bulldozer neo-liberalism in Istanbul: The state-led construction of property markets, and the displacement of the urban poor. International Planning Studies, 16(1), str. 73-96. DOI: 10.1080/13563475.2011.552477

Madanipour, A. (1996): Design of urban space: An inquiry into a socio-spatial process. Chichester, VB, John Wiley \& Sons.

Mokhtar, M. (2007): Aesthetic values in urban design, case study Constantine. Doktorska disertacija. Constantine, Universite Mentouri, Departement d'architecture et d'urbanisme.

Mowla, Q. A. (2011): Urban aesthetics: A study on Dhaka. V: Sharifuddin, A., Hafiz, R., in Golam Rabbani A. K. M. (ur.): The history heritage and urban issues of capital Dhaka, volume-III, urbanization and urban development, str. 169-262. Daka, Asiatic Society of Bangladesh.

Munasinghe, H. (2016): Aesthetics of urban space through collaborative urban planning: Integrating environmental aesthetics with communicative theory of planning. Built-Environment Sri Lanka, 2(1), str. 35-44. DOI: 10.4038/besl.v2i1.7629

Nasar, J. L. (1990): The evaluative image of the city. Journal of the American Planning Society, 56(1), str. 41-53. DOI: $10.1080 / 01944369008975742$

Nasar, J. L. (1994): Urban design aesthetics the evaluative qualities of building exteriors. Environment and Behavior, 26(3), str. 377-401. DOI: $10.1177 / 001391659402600305$

Nasar, J. L. (1997): New developments in aesthetics for urban design. Urban Design Aesthetics, Advances in Environment, Behavior, and Design, 4, str. 149-193. DOI: 10.1007/978-1-4757-4425-5_5

Norton, T. M. (1967): Police power, planning and aesthetics. Santa Clara Lawyer, 7(2), str. 171-187.

Onaran, K. (1995): Protecting the collectively appreciated: Different approaches to aesthetics and aesthetic regulation in the United States. METUJFA, 15(1-2), str. 17-36.

Özalp, S., in Erkut, G. (2016): Kamu yararı perspektifinden İstanbul'da kentsel müdahaleler. Planlama, 26(3), str. 242-245.
Ozkan, H., in Turk, S. S. (2016): Emergence, formation and outcomes of flexibility in Turkish planning practice. IDPR, 38(1), str. 25-54. DOI: $10.3828 /$ idpr.2016.2

Pehlivanoğlu, Y. (2011): Understanding perceptions regarding the aesthetics of urban public space: Tunalı Hilmi Street, Ankara. Magistrska naloga. Ankara, Middle East Technical University.

Porteous, J. D. (1996): Environmental aesthetics: ideas, politics and planning, London, Routledge.

Sahraoui, Y., Clauzel, C., in Foltete, J. C. (2016): Spatial modelling of landscape aesthetic potential in urban-rural fringes. Journal of Environment Management, (181), str. 623-636. DOI: 10.1016/j.jenvman.2016.06.031

Sleegers, F. (2014): Linear infiltration systems along urban streets: Evaluating aesthetic values. Journal of Landscape Architecture, 9(1), str. 48-59. DOI: $10.1080 / 18626033.2014 .898831$

Sternberg, R. (1991): The urban aesthetic in comparative perspective. V: Environmental, Urban and Geographic Studies, str. 70-79. Upper Montclair, NJ, Montclair State College.

Swyngedouw, E., Moulaert, F., in Rodriguez, A. (2002): Neoliberal urbanization in Europe: Large-scale urban development projects and the new urban policy, Antipode, 34(3), str. 547-582. DOI: $10.1111 / 1467-8330.00254$

Taylor, N. (2009): Legibility and aesthetics in urban design. Journal of Urban Design, 14(2), str. 189-202. DOI: 10.1080/13574800802670929

Teymur, N. (1981): Aesthetics of aesthetic, aesthetic question in architectural and urban discourses. M.E.T.U. Journal of the Faculty of Architec ture, 7(1), str. 77-96.

Thibaud, J. (2010) La ville à l'épreuve des sens. V: Coutard, O., in Lévy, J. P. (ur.): Ecologies Urbaines, str. 198-213. Pariz, Editions Economica.

Verdi, L. (2014): Aesthetics in urban space: Architecture and art for sustainable cities. Social Space Journal, 10(12), str. 1-18.

Xianghan, C. (2008): Urban images and urban aesthetics, urban aesthetics in cross cultural perspectives. EFD/JFL, Journal of Faculty of Letters, 25(2), str. 59-71.

Yong, A. G., in Pearce, S. (2013): A beginner's guide to factor analysis: Focusing on exploratory factor analysis. Tutorials in Quantitative Methods for Psychology, 9(2), str. 79-94. DOI: 10.20982/tqmp.09.2.p079 